ISSN: 2224-0616

Int. J. Agril. Res. Innov. Tech. 11(1): 92-100, June 2021

DOI: https://doi.org/10.3329/ijarit.v11i1.54471

\section{OPEN 2 ACCESS}

Available online at https://ijarit.webs.com https://www.banglajol.info/index.php/IJARIT

\title{
Effect of decision variables on yield and water productivity of onion under conventional furrow irrigation system in bako woreda, Ethiopia
}

\author{
G. Genemo ${ }^{1^{*}}$ and T. Seyoum ${ }^{2}$
}

Received 27 April 2021, Revised 17 June 2021, Accepted 23 June 2021, Published online 30 June 2021

\begin{abstract}
A B S T R A C T
Flow rate and furrow length are the main irrigation decision variables currently affecting yield and water productivity at farm level. Improper selection of these variables produces an over use of water and loss in crop production. The general objective was to investigate the effect of decision variables on yield and water productivity of onion under conventional furrow irrigation system, with specific objective to analyze the effect of flow rate, furrow length and their interaction on yield and water productivity of onion. The field experiment was laid out in randomized complete block design with factorial arrangement of three levels of flow rate $(0.7,0.98$ and $1.3 \mathrm{~L} / \mathrm{S})$ and three levels of furrow length $(25,35$ and $50 \mathrm{~m})$ with three replications. Inflow out flow method was used to determine the infiltration characteristics of the soil and Irrigation depth was controlled by using 3-inch Parshall flume. The maximum non-erosive flow rate to the experimental site was fixed through design equation considering soil textural class and furrow bed slope. Effect of furrow length and flow rate on yield and water productivity of the onion were used for evaluation. Their analyses indicated that effect of furrow length and their interaction with flow rate on yield were not significant $(p<0.05)$. However, the flow rate showed highly significant $(p<0.01)$ effect on yield of onion. The ranges of mean yield gained from furrow length and flow rate were F1 (14.75 ton ha-1) to F3 (15.96 ton ha-1) and Q1 (13.59 ton ha-1) to Q3 (19.69 ton ha-1), respectively. The effect of furrow length on crop water use efficiency and field water use efficiency was not significant $(\mathrm{p}<0.05)$. However, the flow rate has showed highly significant $(p<0.01)$ effect on crop water use efficiency and field water use efficiency. The range of mean crop water use efficiency and field water use efficiency from furrow length and flow rate were $F_{1}(33.65 \mathrm{~kg} / \mathrm{ha} / \mathrm{mm})$ to $\mathrm{F}_{3}(36.41 \mathrm{~kg} / \mathrm{ha} / \mathrm{mm})$ and $\mathrm{Q} 1(30.99 \mathrm{~kg} / \mathrm{ha} / \mathrm{mm})$ to Q3 $(38.65 \mathrm{~kg} / \mathrm{ha} / \mathrm{mm})$ and $\mathrm{F} 1\left(2.06 \mathrm{~kg} / \mathrm{m}^{3}\right)$ to $\mathrm{F}_{3}\left(2.23 \mathrm{~kg} / \mathrm{m}^{3}\right)$ and Q1 $\left(1.89 \mathrm{~kg} / \mathrm{m}^{3}\right)$ to $\mathrm{Q} 3(2.36$ $\mathrm{kg} / \mathrm{m}^{3}$ ), respectively. Therefore, it can be concluded that a furrow length of $50 \mathrm{~m}$ is suitable to use $1.3 \mathrm{~L} / \mathrm{S}$ of flow rate for better onion yield and water productivity under similar soil type of study area.
\end{abstract}

Keywords: Conventional furrow, Decision variable, Flow rate, Furrow length, Water productivity.

${ }^{1}$ Oromia Agricultural Research Institute, Bako Agricultural Engineering Research center, Bako, Ethiopia.

${ }^{2}$ School of Water Resources and Environmental Engineering, Haramaya University, Haramaya, Ethiopia.

*Corresponding author's email: 4genemo@gmail.com (Gudeta Genemo)

Cite this article as: Genemo, G. and Seyoum, T. 2021. Effect of decision variables on yield and water productivity of onion under conventional furrow irrigation system in bako woreda, Ethiopia. Int. J. Agril. Res. Innov. Tech. 11(1): 92-100. https://doi.org/10.3329/ijarit.v11i1.54471

\section{Introduction}

Ethiopia has large agricultural sector and water potential. However, growing human population, recurrent drought and periodic floods, complicated with climate change that has been accompanied by severe soil and landscape degradation in some regions contributed to a situation of national food insecurity (FAO, 2011). Increasing population and competition for water due to the development of other water use sectors imposed the improvement of water productivity in irrigated agriculture to ensure sustained production and conservation of limited resource
(Mekonen, 2011). In spite of its enormous potential to ensuring long-term food security in Ethiopia, irrigated agriculture is facing inadequate water management at farm level and poor irrigation efficiency. Inappropriate management of irrigation system has contributed, not only to food insecurity but also to environmental problems including excessive water depletion, water quality reduction, water logging and salinization (Akinbile and Yusoff, 2011). 
In conventional furrow irrigation system significant quantities of irrigation water losses by infiltration and surface runoff which decreased the efficiency of agricultural production. This irrigation system has speed up the processes of decomposition and removal of organic elements and mobile forms of nutrients in the root zone that eventually, brought to soil fertility losses (Karajeh et al., 2000). However, today most farmers use this type of irrigation system due to their simplicity, ease of operation and maintenance and low installation or construction cost. These practices are known to produce a greater chance of waterlogging, tail water losses, salinity hazards, high yield loss and lower economical profit (Walker, 2003). There is a need for basic technical parameters and decision variables such as flow rate, furrow length and cut off time that easily applied to furrow irrigation system design in order to improve for local condition ( $\mathrm{Di} \mathrm{Wu}$ et al., 2017). In furrow irrigation system flow rate and furrow length are the main management and design parameters affecting irrigation efficiency (Eldeiry et al., 2005). However, proper selections of these variables are not well practiced in the study area, even most farmer use conventional furrow irrigation system. The possibility of using optimum or longer furrow length in the farmer field is very low. Therefore, appropriate selections of these variables were significant element for improving yield and water productivity. The main objectives of this study were to investigate the effect of decision variables on yield and water productivity of onion under conventional furrow irrigation system around the study area.

\section{Materials and Methods}

\section{A. Location and climatic characteristics of the study area}

The study area was located at Bako Woreda Dambi Dima kebel, West Shewa Zone, Oromia Regional State with an altitude of $1590 \mathrm{~m}$ above sea level and lies in $9^{\circ} 06^{\prime} \mathrm{N}$ and $37^{\circ} \mathrm{O9}{ }^{\prime} \mathrm{E}$ Latitude and longitude, respectively. Mean monthly minimum and maximum temperature of the area were $13.7^{\circ} \mathrm{C}$ and $28.4^{\circ} \mathrm{C}$ and mean monthly annual dependable and effective dependable rainfall in the area were $808.50 \mathrm{~mm}$ and $482.00 \mathrm{~mm}$, respectively. Figure 2 shows the monthly distributions of reference evapotranspiration (ETo) and effective dependable rainfall of the study area for 31 years (1987 - 2017). The potential evapotranspiration of the study area calculated using the CROPWAT model is more than the effective dependable rainfall in most of the months and in this case, rainfall is insufficient to compensate for the water lost by evapotranspiration. This indicated that most of the crops planted in these months need supplemental irrigation. The effective dependable rainfall is more than of reference evapotranspiration (ETo) during June and July, meaning that no irrigation is required during these months (Fig. 1).

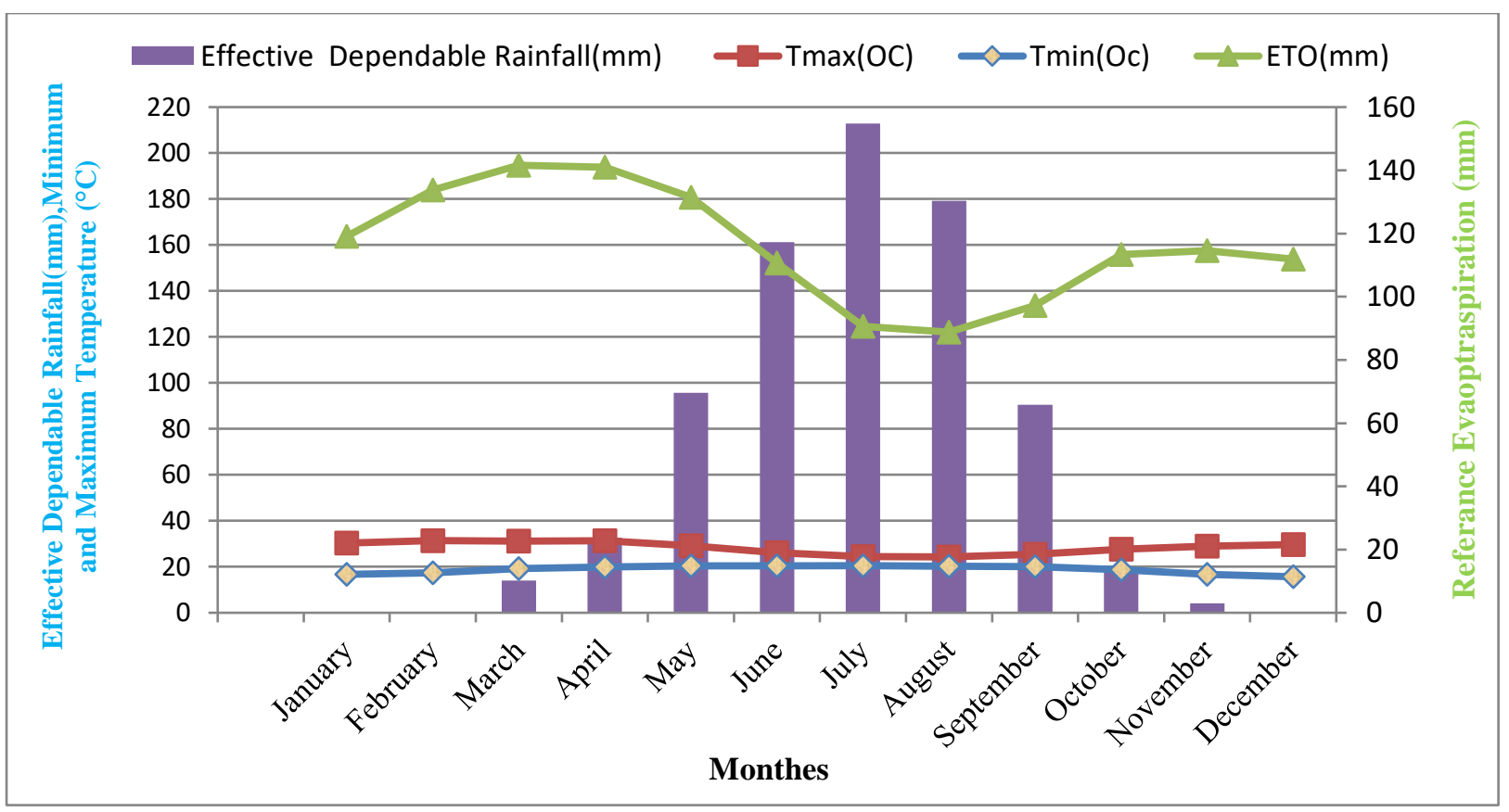

Fig. 1. Monthly distribution of reference evapotranspiration and effective dependable rainfall of study area. 


\section{B. Experimental design and treatments}

The treatments include two factors namely furrow length and flow rate. The levels of treatments include three level of both furrow length (F1, F2, and F3) and flow rate $(\mathrm{Q} 1, \mathrm{Q} 2$, Q3). The furrow length was $25 \mathrm{~m}, 35 \mathrm{~m}$ and $50 \mathrm{~m}$. The flow rate was made by rating of $50 \%, 75 \%$ and $100 \%$ of the maximum non-erosive flow rate. The experimental field was arranged $3 \times 3$ factorial experiments in randomized complete block design with three replications. Each replication had nine treatments or plots and each plot had four furrows with $2.4 \mathrm{~m}$ width. The treatments were assigned randomly into three blocks. The block and plot spacing were $1.5 \mathrm{~m}$ and $0.5 \mathrm{~m}$, respectively.

Table 1. Combinations of experimental treatment.

\begin{tabular}{|c|c|c|c|}
\hline Flow rate $(\mathrm{L} / \mathrm{S})$ & \multicolumn{3}{|c|}{ Furrow Length(m) } \\
\hline & F1 & F2 & F3 \\
\hline Q1 & F1Q1 $(\mathrm{T} 1)$ & F2Q1 $(\mathrm{T} 4)$ & F3Q1 $(\mathrm{T}$ 7) \\
\hline Q2 & F1Q2 (T2) & F2Q2 (T5) & F3Q2 (T8) \\
\hline Q3 & F1Q3 (T3) & F2Q3 (T6) & F3Q3 (T9) \\
\hline
\end{tabular}

\section{Soil sample collection and analysis methods}

The disturbed and undisturbed composite soil sample before planting were collected at a depth of o-20 and 20-40 and 40-60 cm. Bulk density, soil texture, $\mathrm{pH}$, electrical conductivity, field capacity and permanent wilting point were done by core sampler method, pipette method, $\mathrm{pH}$ meter, electro conductivity meter, pressure plate apparatus by applying a suction of $1 / 3$ and 15 bars to a saturated soil sample, respectively.

\section{Determination of infiltration characteristics of the soil}

The two-point method was used for determining the infiltration characteristics of the soil. In the two-point method the infiltration characteristics were described by the modified Kostiakov equation (Elliott and Walker, 1982).

$$
Z=\mathrm{K} \tau^{a}+f o \tau
$$

Where; $\quad \mathrm{Z}=$ cumulative infiltration per unit length of furrow $\left(\mathrm{m}^{3} / \mathrm{m} / \mathrm{m}\right)$

$\tau=$ intake opportunity time (min), for any point $\mathrm{X}$ along furrow length

fo $=$ basic infiltration rate $(\mathrm{m} 3 / \mathrm{min} / \mathrm{m} / \mathrm{m})$

$\mathrm{K}$ and $\mathrm{a}=$ Infiltration parameters

The basic infiltration rate (fo) was determined by using inflow out flow method and The infiltration parameters of Kostiakov Lewis equation ' $\mathrm{K}$ and a' were determined by two point method using a simple volume balance equation considering the volume of water at mid and end of furrow length as described by (Elliott and Walker, 1982) .

\section{E. Determination of crop water requirement and irrigation requirement}

Crop water requirement of onion for the growing season was determined from the reference evapotranspiration and crop coefficient using Equation (2) by using FAO CROPWAT version_8 program. After then the net irrigation requirement was determined (Allen et al., 1998). Dependable Rain (FAO/AGLW) Formula was used to determine effective rainfall. Finally gross irrigation requirement was calculated by considering $60 \%$ of field application efficiency.

$$
E T_{C}=E T_{O} \times K_{C}
$$

Where: $\quad \mathrm{ET}_{\mathrm{C}}=$ crop water requirement or crop evapotranspiration (mm/day)

$\mathrm{K}_{\mathrm{C}}=$ crop coefficient (dimensionless)

$\mathrm{ET}_{\mathrm{O}}=$ reference crop evapotranspiration (mm/day)

\section{F. Determination of Decision variables}

Flow Rate (Qo): Flow rate must not exceed the maximum allowable non-erosive amount. The maximum non-erosive flow rate was determined using equation developed by (Hamad and Stringham, 1978).

$\mathrm{Qmax}=\frac{\alpha}{\mathrm{S}^{\beta}}$

Where;

$\mathrm{Qmax}=$ Maximum flow rate, $\mathrm{L} / \mathrm{S}$

$\mathrm{S}=$ Furrow bed slope, \%

$\alpha$ and $\beta$ are coefficient of parameters based on soil group

Table 2. Coefficient parameters for furrow maximum flow rate.

\begin{tabular}{|l|c|c|}
\hline Soil group & $a(\mathrm{~L} / \mathrm{S})$ & $\mathrm{B}$ \\
\hline Heavy textured & 0.892 & 0.937 \\
\hline Medium heavy textured & 0.988 & 0.55 \\
\hline Medium textured & 0.613 & 0.733 \\
\hline Light textured & 1.111 & 0.615 \\
\hline Very light textured & 0.665 & 0.548 \\
\hline
\end{tabular}


The experimental field had an average of furrow bed slope of $0.6 \%$ and clay loam in textural class, which categorized as medium heavy textured soil group (FAO, 1991). Based on these the coefficient parameters for furrow maximum flow rate were $\alpha=0.988$ and $\beta=0.550$. Therefore the maximum non-erosive flow rate (Qmax) obtained above formula was $1.31 \mathrm{~L} / \mathrm{S}$ and based on this values the three levels of flow rate $50 \%, 75 \%$ and $100 \%$ of Qmax were $0.70,0.98$ and $1.31 \mathrm{~L} / \mathrm{S}$, respectively. These flow rates were diverted to the furrows by using calibrated parshall flume having appropriate opening diameter of three inch (3") and the time required to deliver the desired depth of water into each furrow was calculated using the equation recommended by (Israelsen and Hansen, 1980).

$$
\mathrm{t}=\frac{\mathrm{d} \times \mathrm{w} \times \mathrm{l}}{360 \times \mathrm{q}}
$$

Where; $d=$ gross depth of water applied $(\mathrm{cm})$ $\mathrm{t}=$ application time $(\mathrm{hr})$

$\mathrm{l}=$ furrow length $(\mathrm{m}), \mathrm{w}=$ furrow spacing $(\mathrm{m})$ $\mathrm{q}=$ flow rate $(\mathrm{L} / \mathrm{S})$

The calibration was done by volumetric measurement and Equations obtained from field calibration was checks with the standard (Skogerboe et al., 1967). The different head discharge relation and results were presented in figure 2 .

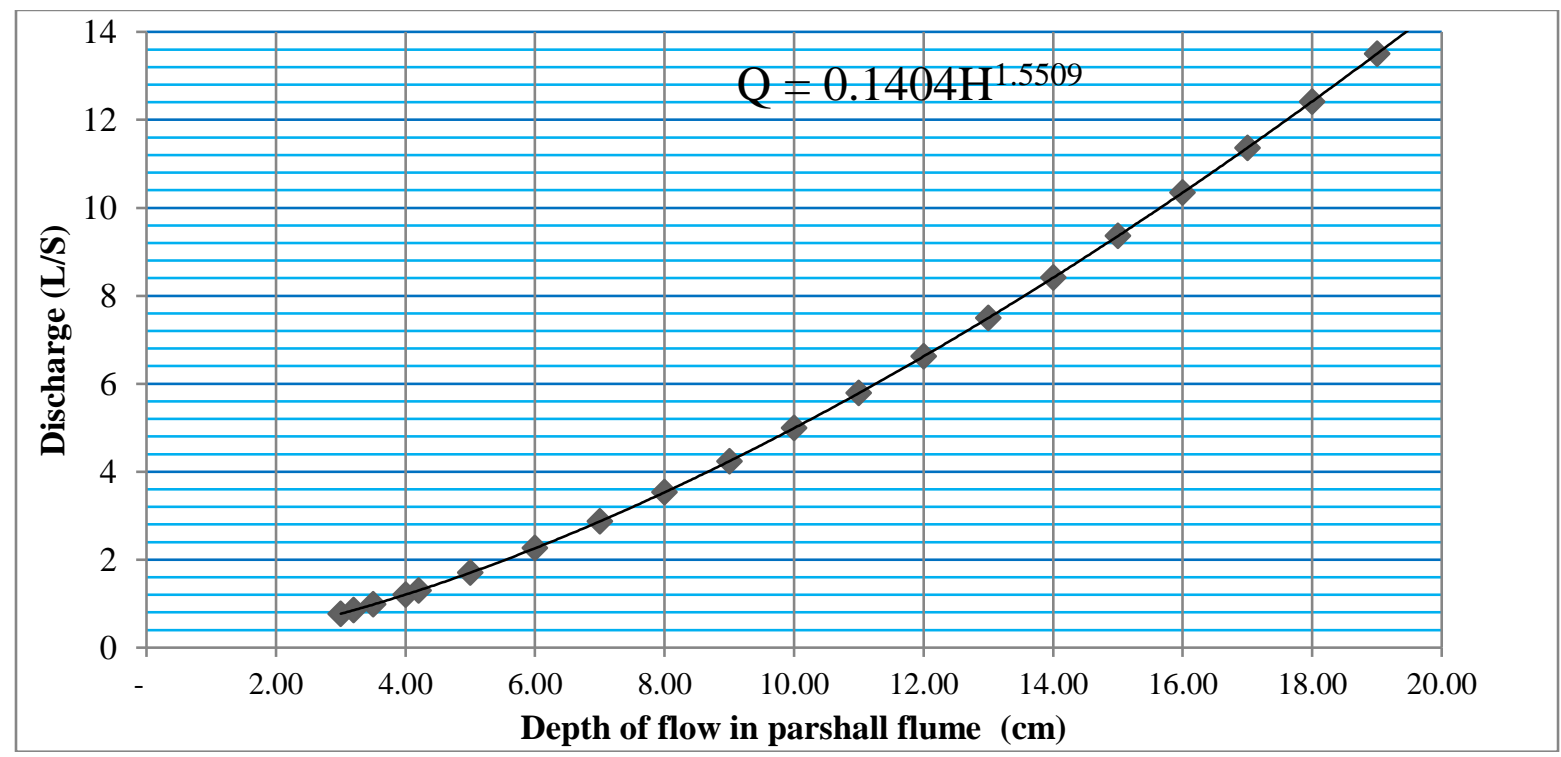

Fig. 2. Head Discharge Relationship of 3 inch parshall flume.

Furrow length: The three furrow length levels were 25,35 and $50 \mathrm{~m}$. The selection of these furrow lengths were based on the existing furrow lengths being practiced by small scale irrigation farmers in the study area. As observed from field survey interviewing agricultural experts, the majority of farmers irrigated land is in the range of 25 - $50 \mathrm{~m}$ long. So, the lower and the upper values were taken and the third one was decided to be in between the two values.

\section{G. Determination of yield and water productivity of onion}

1. Water Productivity in terms of Water Use (Crop Water Use Efficiency)

Crop water use efficiency (CWUE) was computed as the ratio of yield obtained to the seasonal evapotranspiration of the crop.

$$
C W U E=\frac{Y}{E T C}
$$

Where:

CWUE $=$ Crop water use efficiency $(\mathrm{kg} / \mathrm{ha} / \mathrm{mm})$
ETc $=$ Evapotranspiration of crop $(\mathrm{mm})$

$\mathrm{Y}=$ Yield of crop (kg/ha)

2. Water productivity in terms of water applied (Field water use efficiency)

Field water use efficiency (FWUE) was computed as the ratio of yield obtained to the total volume of water applied to the field. Since there was a rainfall during experimental period, the total volume of water applied to the field was the sum of total water diverted to the field (gross irrigation) and effective rainfall.

$$
F W U E=\frac{Y}{W A}
$$

Where: FWUE $=$ Field water use efficiency $\left(\mathrm{kg} / \mathrm{ha} / \mathrm{m}^{3}\right)$ and

$\mathrm{WA}=$ total volume of water applied to the field $\left(\mathrm{m}^{3}\right)$

\section{Yield Collection}

Sample yield was collected from each treatment plots. Each treatment plots has four rows. The 
border rows were used as buffer of middle rows, and sample yield was collected from this two middle rows and the collected yield was weighted separately. The results were then converted ton basis using the following formula:

Onion yield $\left(\right.$ ton $\left.\mathrm{ha}^{-1}\right)=\frac{\text { plot yield }(\mathrm{kg}) \times 10}{\text { plot area }\left(\mathrm{m}^{2}\right)}$

\section{F. Statistical analysis}

The collected data were analyzed using SAS 9.0 statistical software. For comparing means of the treatments that showed significant result, the least significant difference (LSD) test at 5\% and $1 \%$ probability level was applied.

\section{Results and Discussion}

\section{A. Physical and chemical properties of soil}

The laboratory results of the average soil physical and chemical properties of the experimental site were presented in Table below. The result of the soil analysis from the experimental site showed that the average composition of sand, silt and clay percentages were $32.33,31.33$ and $36.33 \%$, respectively (Table 3 ). Thus, according to the USDA soil textural classification, the soil of experimental site could be classified as clay loam soil. The average soil bulk density $\left(1.3 \mathrm{~g} / \mathrm{cm}^{3}\right)$ is below the critical threshold level $\left(1.4 \mathrm{~g} / \mathrm{cm}^{3}\right)$ and was suitable for crop root growth. Average moisture content of soil at field capacity of the experimental site was $30.30 \%$ and at permanent wilting point had $\mathbf{1 5 . 0 6 \%}$ through one-meter soil depth. Based on these the total available water at different depth of onion was 194.92, 192.92 and $206.5 \mathrm{~mm} / \mathrm{m}$ for $0-20 \mathrm{~cm}, 20-40 \mathrm{~cm}$ and $40-60$ $\mathrm{cm}$, respectively and average of total available water of experimental site was $198.11 \mathrm{~mm} / \mathrm{m}$ (Table 3).

The average $\mathrm{pH}$ of the soil for experimental site was 7.12. This shows the soil of the experimental site is normal and suitable for crop production (Savva and Frenken, 2002). Hence, onion can grow with in this soil condition and the finding is in line with (Olani and Fikre, 2010), they conclude that favorable soil $\mathrm{pH}$ range of onion between 6.0 and 8.0. The soil has an average electrical conductivity of $0.26 \mathrm{dS} / \mathrm{m}$ through $60 \mathrm{~cm}$ soil profile, which is below the threshold value for yield reduction, i.e. $1.2 \mathrm{dS} / \mathrm{m}$ (Smith et al., 2011).

Table 3. Soil physical and chemical properties of experimental site.

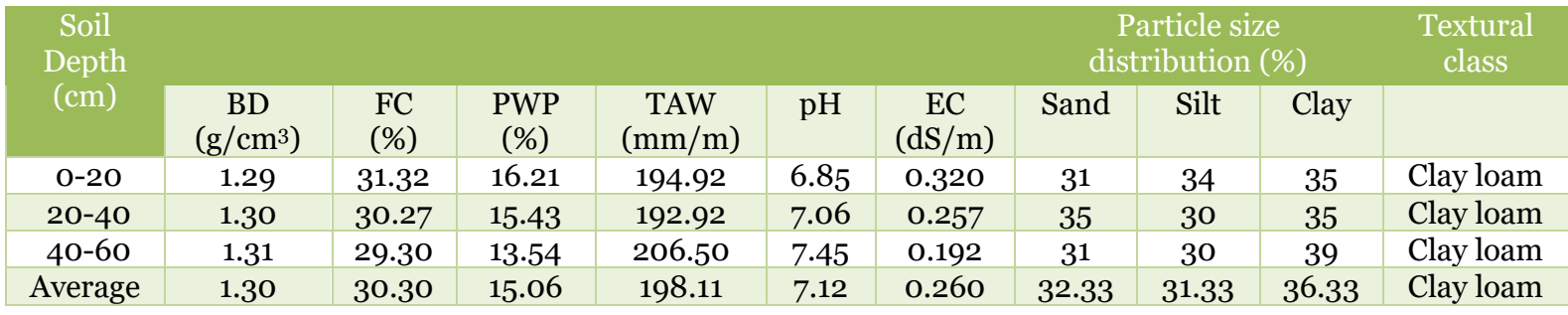

Note: $B D=$ Bulk density, $F C=$ Field capacity, $P W P=$ permanent wilting point, $T A W=$ total available water, $E C=$ electrical conductivity

\section{B. Infiltration characteristics of the soil}

A sample of inflow outflow hydrography for treatment of $\mathrm{F}_{3} \mathrm{Q} 3\left(\mathrm{~F}_{3}=50 \mathrm{~m}\right.$ and $\left.\mathrm{Q} 3=1.3 \mathrm{~L} / \mathrm{S}\right)$ was used to determine the infiltration characteristics of the soil. The inflow-out flow method was used to determine the basic infiltration rate of the soil. The basic infiltration rate was found to be $0.0000967 \mathrm{~m} / \mathrm{min}$ ), which is in the range of (0.000057 to $0.000107 \mathrm{~m} / \mathrm{min}$ ) value for clay loam (Walker, 1989). The infiltration parameters ' $\mathrm{k}$ and a' were found to be $3.64 \mathrm{~mm} / \mathrm{min}^{\mathrm{a}}$ and 0.47 respectively, using a volume balance method as described by (Elliott and Walker, 1982). Based on this depth of water infiltrated along furrow length was determined as follows:

$\mathrm{Z}=3.64 \mathrm{t}^{\mathrm{o} .47}+0.0967 \mathrm{t}$
Where,

$\mathrm{z}=$ depth of water infiltrated along furrow length ( $\mathrm{mm})$ and

$\mathrm{t}=$ intake opportunity time ( $\mathrm{min})$.

Figure 3 shows that the out flow hydrograph, continual rises, which indicates the initial infiltration rate at the inlet of furrow is still significant part of total infiltration. After the flow reached the steady state (basic infiltration rate), the out flow hydrography, drastic falls due to flow velocity become zero and water in the furrow starts to ponding, that make the out flow hydrography tend to zero. This trend is similar to (Walker, 1989), which evaluates inflow out flow hydrography of single furrow irrigation. 


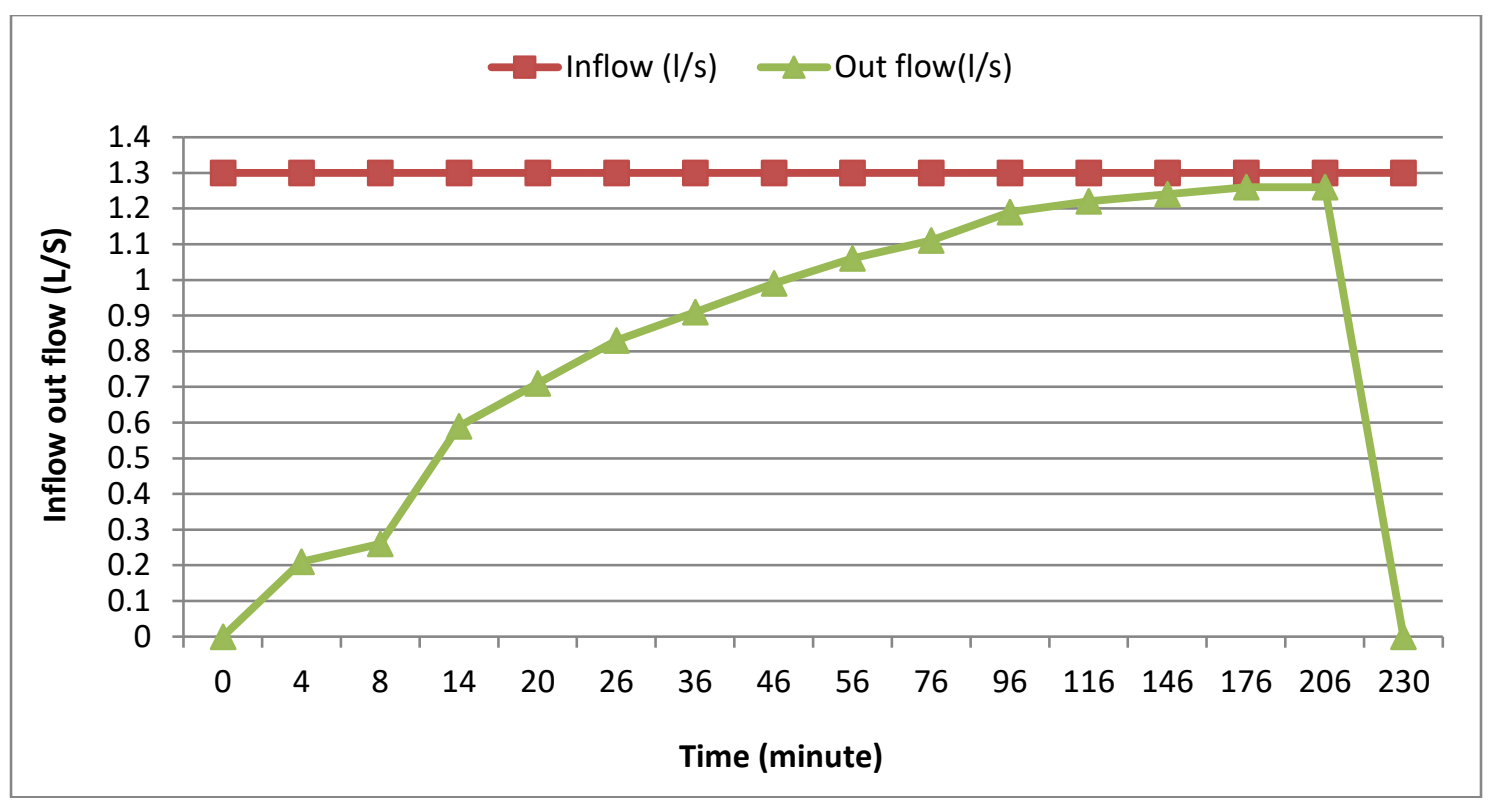

Fig. 3. Inflow out flow hydrograph of F3Q3 for a furrow irrigation evaluation.

\section{Crop water requirements and irrigation scheduling of onion}

Crop water requirements and irrigation scheduling of onion were calculated by multiplying the reference evapotranspiration values with the onion crop coefficient (Allen et al., 1998) and computed as $438.39 \mathrm{~mm}$. The net crop water requirement was computed by deducting effective rainfall from ETc while gross water requirement was computed by adopting a field application efficiency of $60 \%$ were 416.53 $\mathrm{mm}$ and $694.21 \mathrm{~mm}$, respectively(Table 4).

Table 4. Crop water requirement and irrigation requirement of onion.

\begin{tabular}{|c|c|c|c|c|c|c|c|}
\hline \multirow[t]{2}{*}{ Date } & ETo & Crop & ETc & Total Rain & Effective Rain & $\mathrm{IRn}$ & IRg \\
\hline & $\mathrm{mm} /$ period & kc & $\mathrm{mm} /$ period & $\mathrm{mm} /$ period & $\mathrm{mm} /$ period & $\mathrm{mm} /$ period & $\mathrm{mm} /$ period \\
\hline 5-Jan & 23.82 & 0.70 & 16.67 & - & - & 16.67 & 27.79 \\
\hline 11-Jan & 23.82 & 0.70 & 16.67 & - & - & 16.67 & 27.79 \\
\hline 17-Jan & 23.82 & 0.76 & 18.10 & - & - & 18.10 & 30.17 \\
\hline 22-Jan & 19.85 & 0.86 & 17.07 & - & - & 17.07 & 28.45 \\
\hline 29-Jan & 27.79 & 0.97 & 26.96 & - & - & 26.96 & 44.93 \\
\hline 5 -Feb & 4.64 & 1.04 & 32.47 & - & - & 32.47 & 54.11 \\
\hline 12-Feb & 31.22 & 1.04 & 32.47 & & - & 32.47 & 54.11 \\
\hline 20-Feb & 31.22 & 1.04 & 32.47 & 19.80 & 1.88 & 30.59 & 50.98 \\
\hline 1-Mar & 42.48 & 1.05 & 44.60 & & - & 44.60 & 74.34 \\
\hline 10-Mar & 42.48 & 1.05 & 44.60 & 25.00 & 5.00 & 39.60 & 66.01 \\
\hline 20-Mar & 47.20 & 1.05 & 49.56 & 22.30 & $3 \cdot 38$ & 46.18 & 76.97 \\
\hline 31-Mar & 51.92 & 1.05 & 54.52 & - & - & $54.5^{2}$ & 90.86 \\
\hline \multirow[t]{2}{*}{ 11-Apr } & 51.70 & 1.01 & 52.22 & 36.00 & 11.60 & 40.62 & 67.70 \\
\hline & & & 438.39 & 103.10 & 21.86 & 416.53 & 694.21 \\
\hline
\end{tabular}

Note: $\quad$ ETo $=$ reference evapotranspiration, ETc $=$ crop water requirement, $I R n=$ net irrigation Requirement, IRg = gross irrigation requirement and Crop $k c=$ crop coefficient

\section{$D$. Effect offlow rate and furrow length on Yield and water productivity}

According to the analysis of variance (Table 5), the effect of flow rate on yield was highly significant $(\mathrm{p}<0.01)$. However, the effect of furrow length and its interaction with flow rate could not show any significant effect $(\mathrm{P}<0.05)$ on the onion yield. The analysis of variance showed that the effect of flow rate on crop water use efficiency was highly significant $(\mathrm{p}<0.01)$, but the effect of furrow length and its interaction with flow rate could not show any significant effect $(\mathrm{P}<0.05)$ on crop water use efficiency (Table 5). Similarly, the effect of flow rate on field water use efficiency was highly significant $(p<0.01)$, but effect of furrow length and its interaction with flow rate could not show any significant effect $(\mathrm{P}<0.05)$ on field water use efficiency (Table 5$)$. 
Table 5. Analyses of variance (ANOVA) for yield and water productivity.

\begin{tabular}{|l|l|l|l|}
\hline Source of variation & \multicolumn{2}{l|}{ Yield and water productivity } & \\
\hline Furrow length(F) & Y (ton ha-1) & CWUE $(\mathrm{kg} / \mathrm{ha} / \mathrm{mm})$ & FWUE $\left(\mathrm{kg} / \mathrm{ha} / \mathrm{m}^{3}\right)$ \\
\hline Flow Rate(Q) & $1.92^{\mathrm{ns}}$ & $3.63^{\mathrm{ns}}$ & $1.92^{\mathrm{ns}}$ \\
\hline FXQ & $11.36^{* *}$ & $11.36^{* *}$ & $0.36^{* *}$ \\
\hline CV (\%) & $0.42^{\text {ns }}$ & $0.41^{\mathrm{ns}}$ & 9.90 \\
\hline LSD(0.05) & 9.90 & 9.90 & 0.209 \\
\hline
\end{tabular}

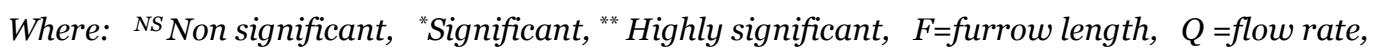
$F X Q=$ interaction of furrow length and flow rate, $Y=$ yield, $C W U E=$ crop water use efficiency,

FWUE = field water use efficiency

\section{Effect of Decision variables on yield of onion}

As indicated in Table 5, the analysis of variance showed that the effect of flow rate on yield was highly significant $(\mathrm{p}<0.01)$. However, the effect of furrow length and its interaction with flow rate could not show any significant effect $(\mathrm{P}<0.05)$ on the onion yield. The mean of onion yield obtained were $13.59,14.95$ and 19.61 ton ha-1 for $0.70,0.98$ and $1.30 \mathrm{~L} / \mathrm{S}$ flow rate, respectively and the better yield were obtained at higher flow rate and increases as flow rate increase (Table 6). This agreed with the trend of Eduardo et al. (2010), they obtained the highest yield at higher furrow irrigation inflow rate. The effect of furrow length could not show any significant effect $(\mathrm{P}<0.05)$ on the onion yield (Table 5). The Minimum and maximum onion yield obtained from the furrow length F1 (14.75 ton ha' ${ }^{-1}$ ) and F3 (15.96 ton ha' ${ }^{-1}$ ). In fact as irrigation is uniform and meets crop water requirements, the crop production increases. This indicates an increase in crop yield is linked with uniformity of water application rather than increases of furrow length. Similar trend were reported with Assefa et al. (2017) and Tefera et al. (2016) their study showed that there was no statistically significance difference of crop yield influencing furrow length except flow rate.

The interaction effect of furrow length and flow rate could not show any significant effect $(\mathrm{P}<0.05)$ on the onion yield (Table 5). The maximum yield was obtained at $1.30 \mathrm{~L} / \mathrm{S}$ flow rate. Since there is no significance of onion yield difference between levels of furrow length, the higher levels of two treatments with $1.30 \mathrm{~L} / \mathrm{S}$ flow rate have good yield potential.

Table 6 . Effect of flow rate and furrow length on yield and water productivity.

\begin{tabular}{|l|c|c|c|}
\hline Decision variable & Yield $\left(\right.$ ton ha $\left.{ }^{-1}\right)$ & CWUE $(\mathrm{kg} / \mathrm{ha} / \mathrm{mm})$ & FWUE $\left(\mathrm{kg} / \mathrm{m}^{3}\right)$ \\
\hline Furrow length $(m)$ & $14.75^{\mathrm{b}}$ & $33.65^{\mathrm{c}}$ & $2.06^{\mathrm{a}}$ \\
\hline F1 & $14.77^{\mathrm{b}}$ & $33.69^{\mathrm{c}}$ & $2.06^{\mathrm{a}}$ \\
\hline F2 & $15.96^{\mathrm{b}}$ & $36.41^{\mathrm{d}}$ & $2.23^{\mathrm{a}}$ \\
\hline F3 & 0.500 & 1.14 & 0.07 \\
\hline SEM $( \pm)$ & 1.49 & $3.4^{\mathrm{d}}$ & 0.209 \\
\hline LSD(0.05) & & & \\
\hline Flow rate $(L / S)$ & $13.59^{\mathrm{h}}$ & $30.99^{\mathrm{m}}$ & $1.89^{\mathrm{i}}$ \\
\hline Q1 & $14.95^{\mathrm{h}}$ & $34.10^{\mathrm{n}}$ & $2.08^{\mathrm{j}}$ \\
\hline Q2 & $19.61^{\mathrm{g}}$ & $38.65^{\mathrm{p}}$ & $2.36^{\mathrm{k}}$ \\
\hline Q3 & 0.500 & 1.14 & 0.07 \\
\hline SEM( \pm$)$ & 1.49 & 3.42 & 0.209 \\
\hline LSD(0.05) & & & \\
\hline
\end{tabular}

*Means with the same letter are not significantly different. 2. Effect of flow rate and furrow length on water
productivity

Crop water use efficiency

As indicated in Table 5, the analysis of variance showed that the effect of flow rate on crop water use efficiency was highly significant $(\mathrm{p}<0.01)$. The mean of crop water use efficiency obtained was $30.99,34.10$ and $38.65 \mathrm{~kg} / \mathrm{ha} / \mathrm{mm}$ for flow rate of $0.70,0.98$ and $1.30 \mathrm{~L} / \mathrm{S}$ flow rate, respectively. The crop water uses efficiency increase with increasing of flow rate. The minimum and maximum crop water use efficiency was obtained from the flow rate of Q1 (30.99 kg/ha/mm) and Q3 $(38.65 \mathrm{~kg} / \mathrm{ha} / \mathrm{mm})$, respectively. The maximum crop water use efficiency was obtained at higher flow rate (Table 6). The effect of furrow length and its interaction with flow rate could not show significant effect $(\mathrm{P}<0.05)$ on crop water use efficiency (Table 5). The minimum and maximum crop water use efficiency was obtained from the furrow length of 
F1 (33.65 kg/ha/mm) and F3 $(36.41 \mathrm{~kg} / \mathrm{ha} / \mathrm{mm})$. However, there was no variation from furrow length F1 (33.65 $\mathrm{kg} / \mathrm{ha} / \mathrm{mm})$ to $\mathrm{F} 2 \quad(33.69$ $\mathrm{kg} / \mathrm{ha} / \mathrm{mm}$ ) as shown in the Table 6 . The variation of crop water use efficiency is not the increasing of furrow length. The increment of crop water use efficiency at each level of treatments does not have statistically significance difference expect flow rate as shown Table 5 . This shows the interaction effect of furrow length and flow rate could not show any significant effect $(\mathrm{P}<0.05)$ on the crop water use efficiency. Tefera et al. (2016) also reported similar trend.

\section{Field water use efficiency}

As shown on analysis of variance (Table 5), effect of furrow length and its interaction with flow rate could not show any significant effect $(\mathrm{P}<0.05)$ on field water use efficiency. The mean of field water use efficiency obtained were 2.06, 2.06 and 2.23 $\mathrm{kg} / \mathrm{m}_{3}$ for furrow length of $\mathrm{F}_{1}, \mathrm{~F}_{2}$ and $\mathrm{F}_{3}$, respectively. The minimum and maximum field water use efficiency was obtained from furrow length of $F_{1}\left(2.06 \mathrm{~kg} / \mathrm{m}_{3}\right)$ and $F_{3}\left(2.23 \mathrm{~kg} / \mathrm{m}_{3}\right)$, respectively (Table 6). However, the effect of flow rate on field water use efficiency was highly significant $(\mathrm{p}<0.01)$. The mean of field water use efficiency obtained were $1.89,2.08$ and 2.36 $\mathrm{kg} / \mathrm{m} 3$ for flow rate of $0.70,0.98$ and $1.30 \mathrm{~L} / \mathrm{S}$, respectively. The minimum and maximum field water use efficiency was obtained from flow rate of Q1 (1.89 kg/m3) and Q3 (2.36 kg/m3), respectively. As shown in Table 6, the maximum FWUE and CWUE was observed at 100\% Qmax or Q3. Therefore, the trend of FWUE and CWUE in this experiment is in agreement with the findings of Simsek et al. (2005) who reported that maximum FWUE and CWUE were obtained in treatment with full irrigation level (100\% of Crop water requirement).

\section{Conclusions and Recommendation}

Furrow irrigation is not only the primary consumer of water but it is also the most inefficient user. Considering this issues, a study was conducted to evaluate effect of decision variables on yield and water productivity of onion under conventional furrow irrigation system. Results analyses of variance showed that the effect of furrow length and its interaction with flow rate on yield of onion was not significant $(\mathrm{p}<0.05)$. However, the flow rate showed highly significant $(\mathrm{p}<0.01)$ effect on yield of onion. The best onion yield was obtained at Q3, which gave 19.61 ton $\mathrm{ha}^{-1}$. The effect of furrow length and its interaction with flow rate could not show significant effect $(\mathrm{P}<0.05)$ on crop water use efficiency. However, the effect of flow rate on crop water use efficiency was highly significant $(\mathrm{p}<0.01)$. The minimum and maximum crop water use efficiency was obtained from the flow rate of Q1 (30.99 $\mathrm{kg} / \mathrm{ha} / \mathrm{mm})$ and Q3 (38.65 $\mathrm{kg} / \mathrm{ha} / \mathrm{mm}$ ), respectively. The maximum crop water use efficiency was obtained at higher flow rate (Q3) which gave $38.65 \mathrm{~kg} / \mathrm{ha} / \mathrm{mm}$. The effect of furrow length and its interaction with flow rate could not show any significant effect $(\mathrm{P}<0.05)$ on field water use efficiency. The minimum and maximum field water use efficiency was obtained from furrow length of $\mathrm{F}_{1}\left(2.06 \mathrm{~kg} / \mathrm{m}^{3}\right)$ and $\mathrm{F}_{3}$ $\left(2.23 \mathrm{~kg} / \mathrm{m}^{3}\right)$, respectively. However, the effect of flow rate on field water use efficiency was highly significant $(\mathrm{p}<0.01)$. The mean of field water use efficiency obtained were $1.89,2.08$ and 2.36 $\mathrm{kg} / \mathrm{m}^{3}$ for flow rate of $0.70,0.98$ and $1.30 \mathrm{~L} / \mathrm{S}$, respectively. The minimum and maximum field water use efficiency was obtained from flow rate of Q1 $\left(1.89 \mathrm{~kg} / \mathrm{m}^{3}\right)$ and Q3 $\left(2.36 \mathrm{~kg} / \mathrm{m}^{3}\right)$, respectively. In this study, the use of short furrow length was the major contributor of water loss either deep percolation or surface run off and reduced crop yield. Hence, in the utilization of fragmented farm size, a $50 \mathrm{~m}$ furrow length is suitable to use $1.30 \mathrm{~L} / \mathrm{S}$ flow rate for better onion yield and water productivity around the study area.

\section{Acknowledgements}

The authors would like to acknowledge Agricultural Engineering Directorate, Oromia Agricultural Research Institute for providing the required budget to conduct the experiment. Besides, I would like to thanks the Soil Laboratory Technicians of Oromia Water Works Design and Supervision Enterprise, Bako and Holota Agricultural Research Center for their effective and enthusiastic work in soil analysis.

\section{References}

Akinbile, C.O. and Yusoff, M.S. 2011. Environmental Impact of Leachate Pollution on Groundwater Supplies in Akure, Nigeria. Int. J. Environ. Sci. Dev. 2(1): 81-86. https://doi.org/10.7763/IJESD.2011.V2.101

Allen, R., Pereira, L.A., Raes, D. and Smith, M. 1998. Crop evapotranspiration. Irrigation and Drainage Paper No. 56, FAO. Rome, Italy. pp. 130-138.

Assefa, S., Kedir, Y. and Alamirew, T. 2017. Effect of slopes, furrow lengths and inflow rates on irrigation performances and yield of sugarcane plantation at Metehara, Ethiopia. Irrig. Drain. Syst. Eng. 6: 179. https://doi.org/10.4172/2168-9768.1000179

Di Wu, Jingyuan Xue, Xiaodong Bo, Weichao Meng, Youjie Wu and Taisheng Du. 2017. Simulation of Irrigation Uniformity and Optimization of Irrigation Technical Parameters Based On the SIRMOD Model under Alternate Furrow Irrigation. Irrig. Drain. 66: 478-491.

https://doi.org/10.1002/ird.2118 
Eduardo, A.H., Carlos, L., Migue, A.M., Jerónimo, P., José, L.A. and Max, B. 2010. Furrow Irrigation Management and Design Criteria Using Efficiency Parameters and Simulation Models. Chilean J. Agril. Res. 70(2): 287-296.

https://doi.org/10.4067/So718-58392010000200012

Eldeiry, A., Garcia, L.A, El-Zaher, A.S. and Kiwan, M.E. 2005. Furrow irrigation system design for clay soils in arid regions. Appl. Eng. Agric. 21: 411-420. https://doi.org/10.13031/2013.18460

Elliott, R.L. and Walker, W.R. 1982. Field evaluation of furrow infiltration and advance function. Transaction of the ASAE. 25(2): 396-400. https://doi.org/10.13031/2013.33542

FAO. 1991. Manual for the Design and Construction of Water Harvesting Schemes for Plant Production. Food and Agricultural Organization, Rome. pp. 30-31.

FAO. 2011. State of Food Insecurity in the World: How Does International Price Volatility Affect Domestic Economies a Food Security? 50p. ISBN 978-92-5-106927-1.

Hamad, N.S. and Stringham, G.E. 1978. Maximum non-erosive furrow irrigation stream size. J. Irrig. Drain. 104: 275-279. https://doi.org/10.1061/JRCEA4.0001208

Israelsen, O.W. and Hansen, V.E 1980. Irrigation Principles and Practices. Jonsen Wiley and Sons, Inc. New York, London. pp. 290-300.

Karajeh, F., Mukhamedjanov, V. and Vyshepolskiy, F. 2000. On-farm water and drainage management strategy in Kazakhstan's Arys-Turkestan area, Taraz, Kazakstan. 49: 35-50.

Mekonen, A. 2011. Deficit irrigation practices as alternative means of improving water use efficiencies in irrigated agriculture. Case study of maize crop at Arba Minch, Ethiopia. African J. Agri. Res. 6(2): 226-235.

Olani, N. and Fikre, M. 2010. Onion seed production techniques. Manual for extension agents and seed producers. FAO, Rome, Italy. pp. 15-20.

Savva, A. and Frenken, K. 2002. Irrigation Manual Module 3: Agronomic aspects of irrigated crop production. Water resources development and management officers and FAO Sub-Regional Office for East and Southern Africa, Harare, Zimbabwe. pp. 4245 .

Simsek, M., Tonkaz, T., Kacira, M., Comlekcioglu, $\mathrm{N}$. and Doga, Z. 2005. The effects of different irrigation regimes on Cucumber (Cucumbis sativus L.) yield and yield characteristics under open field conditions. Agril. Water Manage. 73: 173-191.

https://doi.org/10.1016/j.agwat.2004.10.013

Skogerboe, G.V., Hyatt, M.L., England, J.D. and Johnson, J.R. 1967. Design and calibration of open channel flow measurement structures, Part 2 Parshall flumes. Utah State Univ. 64p.

Smith, R., Biscaro, A., Cahn, M., Daugovish, O., Natwick, E., Nunez, J., Takele, E. and Turini, T. 2011. Fresh-market bulb onion production in California. Publication 7242. University of California, Agricultural and Natural Resource Center. California. 6p. https://doi.org/10.3733/ucanr.7242

Tefera, D.A., Bijman, J. and Slingerland, M.A. 2016. Agricultural coooperatives in Ethiopia: evolution, functions and impact. $J$. Int. Dev. 29(4): 431-453. https://doi.org/10.1002/jid.3240

Walker, W.R. 1989. Guidelines for Designing and Evaluating Surface Irrigation System. Irrigation and drainage paper No. 45. FAO, Rome. 137p.

Walker, W.R. 2003. SIRMOD III Surface Irrigation Simulation, Evaluation, and Design, Guide and Technical Documentation, Utah State University. $146 \mathrm{p}$. 